\title{
Genetic diversity among pearl millet maintainers using microsatellite markers
}

\author{
R. K. KaPila ${ }^{1,2}, \mathrm{R} \cdot \mathrm{S} \cdot \mathrm{Yadav}^{1}, \mathrm{P} \cdot \mathrm{Plaha}^{2}, \mathrm{~K} \cdot \mathrm{N} \cdot \mathrm{RAI}^{3}, \mathrm{O} \cdot \mathrm{P} \cdot \mathrm{Yadav}^{4}, \mathrm{C} \cdot \mathrm{T} \cdot \mathrm{Hash}^{3}$ and C. J. Howarth $^{1}$
}

${ }^{1}$ Institute of Grassland and Environment Research, Aberystwyth SY23 3EB, Wales, UK, E-mail: biotech@hillagric.ernet.in; ${ }^{2}$ Advanced Centre of Hill Bioresources \& Biotechnology, HP Agricultural University, Palampur 176062 , India; ${ }^{3}$ International Crop Research Institute for Semi-Arid Tropics, Patancheru 502 324, India; ${ }^{4}$ Central Arid Zone Research Institute, Jodhpur 342003 , India

With 1 figure and 3 tables

Received December 7, 2006/Accepted May 22, 2007

Communicated by L. Hartl

\begin{abstract}
Genetic diversity among 70 maintainers and two pollinators of sub-Saharan and Indian origin was studied for simple sequence repeat (SSR) loci using 34 primer pairs. A total of 213 alleles were detected with an average of 6.26 alleles per locus. Polymorphic information content (PIC) ranged from 0.05 to 0.96 with a mean of 0.58 for the SSR loci. Mean PIC across the linkage groups and number of alleles in dinucleotide motifs varied significantly. The lowest PIC (0.239) for linkage group 6 indicated comparatively conserved nature of this linkage group. Genetic similarity estimates ranged from 0.05 to 0.73 with an average value of 0.29 . This indicated sufficient diversity among the maintainer and pollinator lines. The 72 lines fell in five clusters, and the clustering pattern corroborated with their pedigree and characteristic traits. Pollinator ICMR 356 was more diverse from the maintainer lines analysed, and can be a potential parent for pearl millet hybrid development.
\end{abstract}

Key words: Pennisetum glaucum — genetic diversity — SSR — ICRISAT

Pearl millet [Pennisetum glaucum (L.) R. Br.] is the fourth most important food crop of the world next to rice, wheat and sorghum. Grown for dual purpose as grain and fodder, its cultivation extends widely from well-irrigated areas to the most arid regions of the world in Asia and Africa. The major constraints to the productivity of crop include lesser area under hybrids and prevalence of different biotic and abiotic stresses.

Recently, for genetic improvement of pearl millet, development of hybrids is being preferred over open-pollinated varieties. Hybrid development in pearl millet was facilitated by the availability of a cytoplasmic male-sterility (CMS) system derived from Tift 23A1 cytoplasm in the early 1960s (Burton 1965). Since then, Tift 23A1 has been used as a source of CMS, which led to genetic uniformity in the seed parents. Realising it, diversification programme of the seed parents of pearl millet hybrid breeding programme was conceived as insurance against the threats of unforeseen diseases and pests. Such diversification involved the use of more than one CMS source coupled with incorporating several diverse nuclear combinations within each source. Consequently, new CMS sources are currently available in pearl millet, and two of these (A4 and A5) are being exploited in the hybrid breeding programme (K. N. Rai, personal communications). As a result, a large number of parental lines (A and $\mathrm{R}$ ) with diverse nuclear as well as cytoplasmic combinations have been generated at the International Crops Research Institute for Semi-Arid Tropics (ICRISAT), India. However, no systematic attempt has been made to assess the extent of genetic diversity in these elite parental lines at the molecular level.

Knowledge of genetic diversity is indispensable in a crop improvement programme particularly in the development of commercial hybrids and can be assessed by using various tools including DNA markers. Of the various DNA markers, restriction fragment length polymorphisms (RFLPs) (Liu et al. 1994, Delorme et al. 1997, Bhattacharjee et al. 2002) and random amplified polymorphic DNA (RAPD) (Chowdari et al. 1998a,b) have been used in a few studies to assess the genetic diversity in pearl millet cultivars and land races. However, recently simple sequence repeats (SSRs) have been adjudged as more reliable DNA markers for such studies because of their multi-allelism, genome specificity, even distribution, high polymorphism and easy detection. In pearl millet, microsatellites have been used to map and transfer drought tolerance quantitative trait loci using marker assisted backcross selection (Yadav et al. 2002a,b). A recent study has reported diversity in wild and cultivated pearl millet accessions of Niger using microsatellite markers (Mariac et al. 2006). However, no study appears to have undertaken to assess diversity in the elite maintainer and restorer lines of pearl millet hybrid breeding programmes using these markers. In this study, we used SSR markers to assess and characterize the pattern of diversity in maintainer and pollinator lines, being used in the ongoing hybrid breeding programmes at ICRISAT, to identify potential parents for the development of commercial hybrids in pearl millet.

\section{Materials and Methods}

A set of 70 maintainer (B) and two promising restorer (R) lines derived from diverse germplasm groups and maintained at the Asia Centre of ICRISAT was used. Different groups of lines on the basis of their characteristic features are presented in Table 1, and pedigrees shown in Supplemental Table 1. Leaves from 10- to 12-day-old seedlings were harvested from each inbred line and DNA extracted using a DNA extraction kit (Phytopure DNA Extraction Kit; Nucleon BioSciences, Glasgow, UK). From the MilletGene database (http://jiio5.jic.bbsrc. ac.uk:8000/millet.html), 42 SSR primer pairs, encompassing at least five SSR loci from each linkage group, were selected to represent the whole nuclear genome. These primers were assayed for their consistency in amplification and polymorphism on a set of 16 pearl millet lines. A final set of 34 primer pairs, representing at least three from each linkage group, was used for further analysis (Supplemental Table 2). On Linkage Group 2, seven additional markers, known to be linked with drought tolerance (Yadav et al. 2002a), were also included. 
Table 1: Grouping of 72 pearl millet inbred lines on the basis of parentage/characteristic features

\begin{tabular}{ll}
\hline Line(s) & \multicolumn{1}{c}{ Characteristic features } \\
\hline 81B, 841B, ICMB 97444, ICMB 91222, ICMB 96222, ICMB 99333 & Downy mildew resistant selections/derivatives \\
863B, ICMB 88004, ICMB 95333, ICMB 95555, ICMB 00999 & Elite lines derived from Togo germplasm of Africa \\
843B, 842 B, ICMB 88006, ICMB 89111, ICMB 91444, ICMB 91777, & 843 B and its derivatives \\
ICMB 94444, ICMB 0088,, ICMB 91666, ICMB 92111, ICMB 92333, \\
ICMB 92444, ICMB 92666, ICMB 92777, ICMB 92888, ICMB 93111, \\
ICMB 93222, ICMB 93333, ICMB 94111, ICMB 94222, ICMB 94333, \\
ICMB 95111, ICMB 95222, ICMB 95444, ICMB 96111, ICMB 96333, \\
ICMB 97222, ICMB 97333, ICMB 98333, ICMB 98555, ICMB 98666, \\
ICMB 99111, ICMB 00222, ICMB 00666, ICMB 00777, ICMB 01444 \\
ICMB 98444, ICMB 99222, ICMB 99555, ICMB 99666, ICMB 00111, \\
ICMB 00333, ICMB 01555, ICMB 01777 & Self pollinated progeny selections \\
ICMB 96444, ICMB 96555, ICMB 96666, ICMB 97555, ICMB 99444, & Derivatives of lines having high head volume \\
ICMB 00444, ICMB 01111 & Derivatives of high tillering Bajra composites \\
ICMB 00555, ICMB 01222, ICMB 01333 & Derivative of germplasm having extra thick panicle \\
ICMB 97111, ICMB 98111 & Pollinators \\
ICMB 98222 & Miscellaneous \\
ICMR 356, ICMP 451P-6 & \\
ICMB 01666, ICMB 98777 & \\
\hline
\end{tabular}

Amplification reactions were carried out in GeneAmp PCR system 2700, a 96-well DNA thermal cycler (Applied Biosystems, Singapore) programmed for 35 cycles with an initial denaturing step of $3 \mathrm{~min}$ at $94^{\circ} \mathrm{C}$. Each cycle consisted of denaturation at $94^{\circ} \mathrm{C}$ for $1 \mathrm{~min}$, followed by primer-specific annealing for $1 \mathrm{~min}$ and extension at $72^{\circ} \mathrm{C}$ for $1 \mathrm{~min}$. After 35 cycles, there was a final extension step of $4 \mathrm{~min}$ at $72^{\circ} \mathrm{C}$. The $25 \mu \mathrm{l}$ reaction mix comprised $13.87 \mu \mathrm{l}$ sterile-distilled water, $0.13 \mu \mathrm{l}(0.65 \mathrm{U})$ of $\mathrm{Taq}$ polymerase (Roche Applied Sciences, Mannheim, Germany), $2.5 \mu \mathrm{l}$ of $10 \mathrm{x}$ PCR buffer with $\mathrm{MgCl}_{2}$ (supplied with enzyme with a composition of $100 \mathrm{~mm}$ Tris- $\mathrm{HCl}, 15 \mathrm{~mm} \mathrm{MgCl}_{2}$ and $500 \mathrm{~mm} \mathrm{KCl}, \mathrm{pH} 8.3$ ), $1.0 \mu \mathrm{l}$ of dNTP (5 mM equimolar solution of each dATP, dCTP, dGTP and dTTP), $1.25 \mu$ each of forward and reverse primers (10 $\mu \mathrm{M}$ solution) and $5 \mu \mathrm{l}$ of template DNA $(10 \mathrm{ng} / \mu \mathrm{l})$. Reactions were stopped with $95 \%$ formamide loading dye. Amplification products from each primer pair were separated on $4.5 \%$ polyacrylamide denaturing gel (BIO-RAD, California, USA, SequiGenGT, $38 \times 50 \mathrm{~cm}$ ) using 73-well comb and visualized by silver staining (Promega Silver Sequencing system, Wisconsin, USA).

Presence or absence of each amplified band was scored as 1 and 0 , respectively, for all markers to generate a binary data matrix. Relative movement of different amplicons and standard molecular-weight marker was used to estimate the sizes of amplified fragments using regression. The genetic diversity of each microsatellite locus was assessed by calculating the frequency of the microsatellite alleles based on polymorphic information content (PIC) using the equation:

$$
\mathrm{PIC}=1-\mathrm{J}=1-\sum_{j=1}^{n} p_{i j}^{2},
$$

where $p_{i j}$ is the frequency of the $j$ th allele for $i$ th marker (Anderson et al. 1993). Estimates of genetic similarity (gs) were calculated for all possible pairs of inbred lines according to Jaccard's similarity coefficient (Jaccard 1908). Cluster analysis based on unweighted pairgroup method with arithmatic average (UPGMA) was performed on matrix of gs estimates using GenStat Version 6.1 and a dendrogram constructed. The data were also used to examine relationships amongst number of alleles, repeat number of dinucleotide motifs and PIC using simple correlation coefficient analysis. For testing differences in PIC across linkage groups and allele number in dinucleotide motif repeats, the data were analysed for single factor analysis of variance following GenStat Version 6.1 using $t$-test.

\section{Results}

Thirty-four primer pairs, used to characterize and evaluate the genetic diversity in $72 \mathrm{~B}$ and $\mathrm{R}$ lines of pearl millet, detected a total of 213 microsatellite alleles. The number of alleles per marker ranged from 2 for SSRs, Xpsmp 2211 and Xpsmp2202 to 15 in $X p s m p 2066$ with a mean of 6.26 (Table 2). PIC varied from 0.054 (Xpsmp2213) to 0.964 (Xpsmp2088) with a mean of 0.582 . Number of alleles had positive correlation $(r=0.58$, $\mathrm{P}=0.0003$ ) with PIC. Number of repeats in the SSR motifs exhibited strong correlation with number of alleles $(r=0.745$, $\left.\mathrm{P}=4.355 \times 10^{-7}\right)$ and PIC $(r=0.456, \mathrm{P}=0.0067)$ also. The 26 dinucleotide repeats (represented as $[\mathrm{MM}] \mathrm{n}$ ), with $\mathrm{n} \leq 15$, $\mathrm{n}=16-30$ and $\mathrm{n}>30$ generated $4.4,5.2$ and 9.1 mean number of alleles, respectively (Table 3). Dinucleotide SSRs having repeat number $(\mathrm{n}>30)$ had significantly more alleles as compared to groups of SSRs having $\mathrm{n} \leq 15$ and $\mathrm{n}=16-30$. However, PIC values did not differ among the three groups of dinucleotide SSRs.

The 32 loci excluding Xpsmp2231 and Xpsmp2229 indicated differential mean PIC across the seven linkage groups (LG 1 to LG 7) in pearl millet $(\mathrm{P}=0.042)$. Mean $\mathrm{PIC}$ ranged from 0.239 (LG 6) to 0.704 for LG 1 (Table 3). LG 6 exhibited significantly lesser PIC (0.239) than the remaining linkage groups, except LG 5.

Genetic similarity estimates calculated among the inbred lines varied from 0.05 (ICMR 356 and ICMB 01666) to a maximum of 0.73 (ICMB 97444 and ICMB 95555) with a mean similarity of 0.29 (Data not shown). The two pollinators, ICMR 356 and ICMP 451P-6, grouped in cluster I and III respectively (Fig. 1). Besides pollinator ICMR 356, the first cluster comprised two subclusters encompassing maintainer lines 81B, 841B, ICMB 98777 and ICMB 95333. The second cluster was the largest and contained 30 lines with four subclusters. All these lines had $843 \mathrm{~B}$ as one of the parents in their pedigree. Maintainer lines, ICMB 97444 and ICMB 95555 , clustered together at $73 \%$ similarity in one of the subclusters. The third cluster included an elite line 863B, pollinator ICMP 451P-6 and four other B lines. The fourth and fifth clusters comprised 14 and 17 maintainer lines, respectively, with three subclusters each. The first subcluster of fifth cluster included five lines, viz., ICMB 00555, ICMB 01222 and ICMB 01333, ICMB 97111 and ICMB 01444. Seven lines, namely, ICMB 99555, ICMB 00111, ICMB 98444, ICMB 01555, ICMB 99666, ICMB 00333 and ICMB 01777 formed the second subcluster, whereas third subcluster included five lines (ICMB 00888, ICMB 91222, ICMB 96222, ICMB 99111 and ICMB 99222). 
Table 2: Number of alleles, size and polymorphic information content (PIC) detected in 72 inbred lines of pearl millet using 34 simple sequence repeat (SSR) loci

\begin{tabular}{|c|c|c|c|c|c|}
\hline SSR locus & $\begin{array}{l}\text { Repeat } \\
\text { unit/motif }\end{array}$ & $\begin{array}{l}\text { Size range of } \\
\text { alleles (bp) }\end{array}$ & $\begin{array}{l}\text { Linkage group } \\
\text { assigned }\end{array}$ & $\begin{array}{l}\text { No. } \\
\text { alleles }\end{array}$ & PIC \\
\hline Xpsmp 2006 & $(\mathrm{GT})_{51}$ & $211-332$ & 1 & 8 & 0.781 \\
\hline Хрsmp 2030 & $(\mathrm{CA})_{11},(\mathrm{GA})_{10}$ & $107-152$ & 1 & 7 & 0.658 \\
\hline Хрsmp 2069 & $(\mathrm{CA})_{19} \mathrm{CTCG}(\mathrm{CA})_{7}$ & $205-223$ & 1 & 5 & 0.623 \\
\hline Xpsmp 2273 & $(\mathrm{GA})_{12}$ & $154-179$ & 1 & 8 & 0.754 \\
\hline Xpsmp 2059 & $(\mathrm{CA})_{10}$ & $117-121$ & 2 & 3 & 0.52 \\
\hline Xрsmp 2066 & $(\mathrm{CA})_{54}$ & $163-266$ & 2 & 15 & 0.84 \\
\hline Xрsmp 2206 & $(\mathrm{GT})_{10}$ & $192-205$ & 2 & 6 & 0.683 \\
\hline Хрsmp 2088 & $(\mathrm{CA})_{24}$ & $128-170$ & 2 & 8 & 0.964 \\
\hline Xpsmp 2201 & $(\mathrm{GT})_{6}$ imp. & $332-370$ & 2 & 5 & 0.275 \\
\hline Хрsmp 2237 & $(\mathrm{GT})_{8}$ & $214-254$ & 2 & 4 & 0.376 \\
\hline Xpsmp2089 & (AC) ${ }_{14}$ imp. & $115-129$ & 2 & 7 & 0.884 \\
\hline Хрsmp 2072 & $(\mathrm{CA})_{24} \mathrm{TC}(\mathrm{TA})_{5}$ & $163-178$ & 2 & 8 & 0.641 \\
\hline Xрsmp 2050 & $(\mathrm{CA})_{12}$ & $98-106$ & 2 & 5 & 0.452 \\
\hline Хрsmp 2211 & $(\mathrm{GT})_{6} \mathrm{imp}$ & $244-246$ & 2 & 2 & 0.454 \\
\hline Хрsmp 2056 & $(\mathrm{CA})_{29},(\mathrm{TA})_{5}$ & $191-226$ & 3 & 8 & 0.88 \\
\hline Xpsmp 2070 & $(\mathrm{CA})_{25},(\mathrm{TA})_{6}$ & $195-255$ & 3 & 7 & 0.563 \\
\hline Хрsmp 2214 & $(\mathrm{GT})_{9}$ & $236-248$ & 3 & 4 & 0.599 \\
\hline Xрsmp 2231 & $(\mathrm{TG})_{12} \mathrm{GG}(\mathrm{TA})_{4}$ & 219-242 & $3 / 2$ & 7 & 0.659 \\
\hline Хрsmp 2008 & $(\mathrm{TG})_{38}+(\mathrm{CT})_{1}$ & $183-295$ & 4 & 7 & 0.587 \\
\hline Xpsmp 2076 & (CA) 15 & $146-158$ & 4 & 3 & 0.517 \\
\hline Хрsmp 2084 & $(\mathrm{CA})_{44}$ & $204-257$ & 4 & 8 & 0.812 \\
\hline Хрsmp 2086 & $(\mathrm{CA})_{13}$ & $106-133$ & 4 & 6 & 0.698 \\
\hline Xpsmp 2001 & $(\mathrm{TC})_{8},(\mathrm{AC})_{47}$ & $187-222$ & 5 & 13 & 0.572 \\
\hline Хрsmp 2202 & $(\mathrm{GT})_{8}$ & $140-156$ & 5 & 2 & 0.346 \\
\hline Хрsmp 2064 & $(\mathrm{CA})_{57}$ & $136-190$ & 5 & 7 & 0.633 \\
\hline Хрsmp 2229 & $(\mathrm{GT})_{5}$ & $230-245$ & $5 / 7$ & 5 & 0.448 \\
\hline Хрsmp 2018 & $(\mathrm{TG})_{31}$ & $154-213$ & 6 & 7 & 0.342 \\
\hline Хрsmp 2213 & $(\mathrm{GT})_{10}$ & $193-218$ & 6 & 3 & 0.054 \\
\hline Хрsmp 2270 & $(\mathrm{GA})_{20} \mathrm{imp}$ & $146-170$ & 6 & 6 & 0.321 \\
\hline Хрsmp 2019 & $(\mathrm{CA})_{38}$ & $191-238$ & 7 & 7 & 0.699 \\
\hline Xpsmp 2040 & $(\mathrm{CA})_{16}$ ? & $137-153$ & 7 & 3 & 0.533 \\
\hline Xpsmp 2224 & $(\mathrm{TG})_{10}$ & $145-150$ & 7 & 3 & 0.461 \\
\hline Хрsmp 2203 & $(\mathrm{GT})_{18} \mathrm{imp}$. & $341-360$ & 7 & 4 & 0.465 \\
\hline \multirow[t]{2}{*}{ Xpsmp 2263} & $(\mathrm{AG})_{33}$ & $191-279$ & 7 & 12 & 0.710 \\
\hline & & Mean & & 6.26 & 0.582 \\
\hline
\end{tabular}

Table 3: Estimates of mean number of alleles and polymorphic information content (PIC) across seven linkage groups and repeat number groups of dinucleotide motifs in pearl millet

\begin{tabular}{lcc}
\hline & Mean allele number & Mean PIC \\
\hline Linkage group & $7.00^{\mathrm{a} *}$ & \\
1 & $6.30^{\mathrm{a}}$ & $0.704^{\mathrm{a}}$ \\
2 & $6.33^{\mathrm{a}}$ & $0.609^{\mathrm{a}}$ \\
3 & $6.00^{\mathrm{a}}$ & $0.681^{\mathrm{a}}$ \\
4 & $7.33^{\mathrm{a}}$ & $0.654^{\mathrm{a}}$ \\
5 & $5.33^{\mathrm{a}}$ & $0.517^{\mathrm{ab}}$ \\
6 & $5.80^{\mathrm{a}}$ & $0.239^{\mathrm{b}}$ \\
7 & $4.40^{\mathrm{a}}$ & $0.574^{\mathrm{a}}$ \\
Dinucleotide repeat number groups & \\
G1 (n $\leq 15)$ & $5.25^{\mathrm{a}}$ & $0.501^{\mathrm{a}}$ \\
G2 (n $=16-30)$ & $9.14^{\mathrm{b}}$ & $0.571^{\mathrm{a}}$ \\
G3 (n $>30)$ & $0.688^{\mathrm{a}}$ \\
\hline
\end{tabular}

Mean values within a subcolumn followed by different letters are statistically different at $\mathrm{P}=0.05$.

\section{Discussion}

\section{Allele number and PIC as influenced by repeat number of motifs and linkage groups}

A wide range of number of alleles and PIC, detected in the maintainers and pollinators, is higher than reported earlier in pearl millet. Bhattacharjee et al. (2002) detected 51 alleles using 16 RFLP probe-enzyme combinations on 25 plants each of 10 accessions of pearl millet. Chowdari et al. (1998b) reported 59 polymorphic loci in $12 \mathrm{~A}$ and $\mathrm{R}$ lines of pearl millet using 14 RAPD primers. In the present study, the number of alleles had positive correlation $(r=0.58, \mathrm{P}=$ 0.0003) with PIC implying that alleles amplified can be indirectly used to assess PIC in pearl millet. Huang et al. (2002) also reported similar results based on SSR data of 998 accessions in wheat. Repeat number of SSR motifs was also found to influence the number of alleles. Therefore, while using such repeats for genetic diversity studies, it would be worthwhile to consider size of the SSR repeat. SSR repeats with longer sequences can be more informative due to their more evolutionary dynamic nature. Similar associations between size of repeat motifs and alleles detected have been reported in other crops like wheat (Huang et al. 2002) and rice (Ni et al. 2002).

There is scanty information in literature on genetic diversity across the linkage groups in pearl millet. Mean PIC varied across the linkage groups in pearl millet. PIC for LG $6(0.239)$ was significantly lesser than the remaining linkage groups, except LG5, indicating evolutionary more dynamic nature of these linkage groups. Recently, a number of reports in cereals have inferred differential contributions of chromosomes/linkage groups towards molecular marker diversity (Graner et al. 1991, Kleinhofs et al. 1993, Boyko et al. 1999, Ma et al. 2001, Huang et al. 2002, Ni et al. 2002). Most of these studies detected low diversity and mapping of the least number of markers to homoeologous group 4 in a diverse group of cereals, and have attributed it to a more conserved nature of such genomic regions in the tribe Triticeae. In pearl millet, LG 6 having the lowest number (5) of SSR markers (K. M. Devos, 


\section{Genetic similarity}

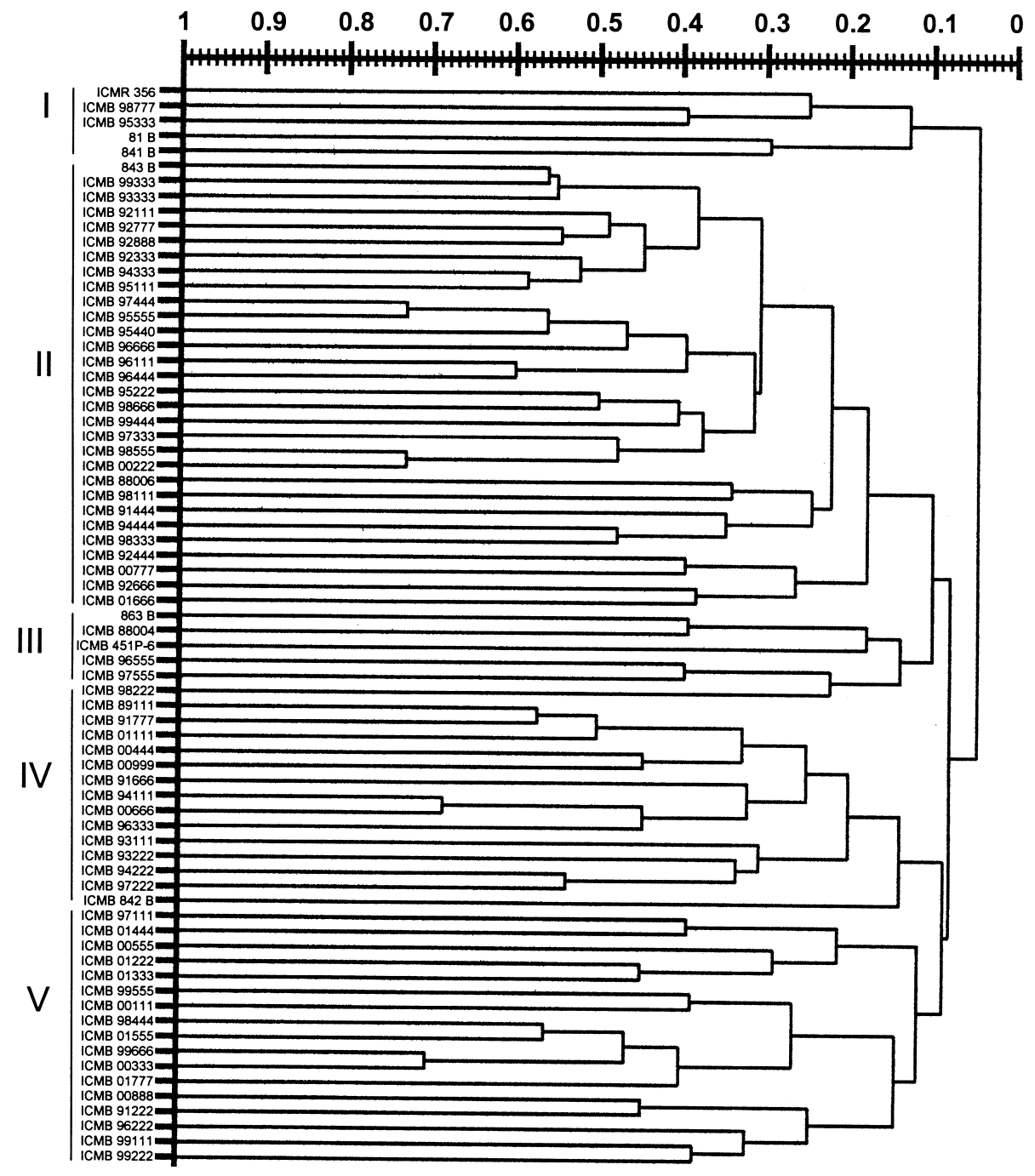

Fig. 1: UPGMA dendogram of 72 inbred lines of pearl millet constructed using genetic similarity matrix

personal communications) and low PIC in present study, has been reported to play a central role in the domestication of this crop (Poncet et al. 2000). Thus, the presence of important genes involved in domestication might be responsible for conserved nature of LG 6 in pearl millet.

\section{Cluster analysis corroborates pedigree/characteristics of lines}

Genetic similarity estimates among the maintainers and pollinators with a mean similarity of 0.29 , indicated considerable diversity among them. From the dendrogram generated, 72 inbred lines could be classified into five main clusters at a threshold gs of 0.12 . The two pollinators, ICMR 356 and ICMP 451P-6, grouped in cluster I and III, respectively, indicating genetic diversity in them. Pollinator ICMR 356, exhibiting high genetic dissimilarity (gs $\leq 0.05$ ) with most of the maintainer lines, except of cluster I, could be promising in hybrid development. Pollinator ICMP 45P-6, grouped in the same cluster with elite lines like $863 \mathrm{~B}$ and had comparatively more genetic similarity (gs) $(\geq 0.05)$ with the maintainer lines, indicated its limited utility for hybrid development. In general, most of the lines closely related by pedigree and/or derived from germplasm having specific traits clustered together. Besides pollinator ICMR 356, the first cluster comprised two subclusters encompassing maintainer lines 81B, 841B, ICMB 98777 and ICMB 95333. Chowdari et al. (1998b) reported clustering of $81 \mathrm{~A}, 841 \mathrm{~A}$ and $5141 \mathrm{~A}$ in the same cluster on the basis of RAPD data of a set of 10 lines. The second cluster was the largest and contained 30 lines with four subclusters. Most of the lines involving $843 \mathrm{~B}$ as one of the parent in pedigree grouped in this cluster. Inbred lines, ICMB 97444 and ICMB 95555 , clustered together at $73 \%$ similarity, had the same selection history, i.e. downy mildew resistant (DMR1) selections. The elite line 863B, pollinator ICMP 451P-6 and four other B lines comprised the third cluster. All the maintainer lines clustered in this group had substantial contribution of African Togo germplasm in their pedigree. Pollinator ICMP 451P-6 also has similar phenotype as the maintainer lines of this group. Some of the lines of this cluster including 863B, known to have inherent drought tolerance mechanisms, have been used as a parent in a mapping population to tag drought tolerance in pearl millet (Yadav et al. 2002a,b). Fourteen inbred lines constituted the fourth cluster, which contained three subclusters. Seventeen lines constituted the fifth cluster, 
which were further subdivided into three subclusters. One of the subclusters included five lines, of which ICMB 00555 , ICMB 01222 and ICMB 01333 are known for their high head volume (HHV). The other two lines, ICMB 97111 and ICMB 01444, are derivatives of HTBC (High Tillering Bajra Composite) and 843B. All lines (ICMB 99555, ICMB 00111, ICMB 98444, ICMB 01555, ICMB 99666, ICMB 00333 and ICMB 01777), except ICMB 99222 derived from crosses involving bold seeded early composite (BSEC) population, obtained from Iniadi landraces of West Africa formed another subcluster. BSEC is known for its traits like bolder seed size and better performance under adverse water stress conditions.

\section{Conclusion and Implications}

The present study demonstrates that SSRs are effective markers for the assessment of genetic diversity in inbred lines of pearl millet. Considerable genetic diversity was detected in the maintainer lines of pearl millet, developed and maintained at ICRISAT, India. This reflects the success of research efforts directed towards diversification of parents for pearl millet hybrid breeding programme. The study reveals that the number of alleles detected for a SSR marker can be a good indicator to assess PIC/diversity, and that selection of the markers based on higher repeat number will be more efficient for genetic diversity studies. ICMP 356 was found to be more diverse and a potential pollinator for the elite CMS lines. Further, the diversity assessed can be manipulated to broaden the genetic base of elite maintainer and CMS lines for the development of commercial hybrid varieties.

\section{Acknowledgements}

We thank Dr MS Dhanoa and Dr Ruth Sanderson for providing help in statistical analysis of data. RK Kapila acknowledges the HP Agricultural University, Palampur, India for granting study leave and the Department of Science \& Technology, Government of India for providing BOYSCAST Fellowship. OP Yadav acknowledges funding from the Royal Society and Indian National Science Academy. This document is an output from a project (Plant Sciences research Programme R6451) funded by the UK Department for International Development (DFID) and administered by the Centre for Arid Zone Studies (CAZS) for the benefit of developing countries. The views expressed are not necessarily those of the DFID.

\section{References}

Anderson, J. A., G. A. Churchill, J. E. Autrique, M. E. Sorrells, and S. D. Tanksley, 1993: Optimising parental selection for genetic linkage maps. Genome 36, $181-186$.

Bhattacharjee, R., P. J. Bramel, C. T. Hash, MA. Kolesnikova-Allen, and I. S. Khairwal, 2002: Assessment of genetic diversity within and between pearl millet landraces. Theor. Appl. Genet. 105, 666-673. Boyko, E. V., K. S. Gill, L. Mickelson-Young, S. Nasuda, W. J. Raupp, J. N. Ziegle, S. Singh, D. S. Hassawi, A. K. Fritz, D. Namuth, N. L. V. Lapitan, and B. S. Gill, 1999: A high density linkage map of Aegilops tauschii, the D-genome progenitor of bread wheat. Theor. Appl. Genet. 99, 16-26.

Burton, G. W., 1965: Pearl millet Tift 23A released. Crops Soils 17, 19 Chowdari, K. V., A. P. Davierwala, V. S. Gupta, P. K. Ranjekar, and O. P. Govila, 1998a: Genotype identification and assessment of genetic relationships in pearl millet [Pennisetum glaucum (L.) R. Br] using microsatellites and RAPDs. Theor. Appl. Genet. 97, 154-162.

Chowdari, K. V., S. R. Venkatachalam, A. P. Davierwala, V. S. Gupta, P. K. Ranjekar, and O. P. Govila, 1998b: Hybrid performance and genetic distance as revealed by the (GATA) $)_{4}$ microsatellite and RAPD markers in pearl millet. Theor. Appl. Genet. 97, 163-169.

Delorme, V., C. L. Keen, K. N. Rai, and C. J. Leaver, 1997: Cytoplasmic-nuclear male sterility in pearl millet: comparative RFLP and transcript analyses of isonuclear male-sterile lines. Theor. Appl. Genet. 95, 961—968.

Graner, A., A. Jahoor, J. Schondelmaier, H. Siedler, K. Pillen, G. Fischbeck, G. Wenzel, and R. G. Herrmann, 1991: Construction of an RFLP map of barley. Theor. Appl. Genet. 83, 250-256.

Huang, X. Q., A. Börner, M. S. Röder, and M. W. Ganal, 2002: Assessing genetic diversity of wheat (Triticum aestivum L.) germplasm using microsatellite markers. Theor. Appl. Genet. 105, 699 - 707.

Jaccard, P., 1908: Nouvelles recherches sur la distribution florale. Bull. Soc. Vaudoise Sci. Nat. 44, 223-270.

Kleinhofs, A., A. Kilian, M. A. Saghai Maroof, R. M. Biyashev, P. Hayes, F. Q. Chen, N. Lapitan, A. Fenwick, T. K. Blake, V. Kanazin, E. Ananiev, L. Dahleen, D. Kudrna, J. Bollinger, S. J. Knapp, B. Liu, M. Sorrells, M. Heun, J. D. Franckowiak, D. Hoffman, R. Skadsen, and B. J. Steffenson, 1993: A molecular, isozyme and morphological map of the barley (Hordeum vulgare) genome. Theor. Appl. Genet. 86, 705-712.

Liu, C. J., J. R. Witcombe, T. S. Pittaway, M. Nash, C. T. Hash, C. S. Busso, and M. D. Gale, 1994: An RFLP-based genetic map in pearl millet (Pennisetum glaucum). Theor. Appl. Genet. 89, 481-487.

Ma, X. F., M. K. Wanous, K. Houchins, M. A. Rodriguez Milla, P. G. Goicoechea, Z. Wang, M. Xie, and J. P. Gustafson, 2001: Molecular linkage mapping in rye (Secale cereale L.). Theor. Appl. Genet. 102, $517-523$.

Mariac, C., V. Luong, I. Kapran, A. Mamadou, F. Sagnard, M. Deu, J. Chantereau, B. Gerard, J. Ndjeunga, G. Bezancon, J. Pham, and Y. Vigouroux, 2006: Diversity of wild and cultivated pearl millet accessions (Pennisetum glaucum [L] R. Br.) in Niger assessed by microsatellite markers. Theor. Appl. Genet. 114, 49-58.

Ni, J., P. M. Colowit, and D. J. Mackill, 2002: Evaluation of genetic diversity in rice subspecies using microsatellite markers. Crop Sci. 42, 601-607.

Poncet, V., F. Lamy, K. M. Devos, M. D. Gale, A. Sarr, and T. Robert, 2000: Genetic control of domestication traits in pearl millet (Pennisetum glaucum L., Poaceae). Theor. Appl. Genet. 100, 147-159.

Yadav, R. S., C. T. Hash, F. R. Bidingar, G. P. Cavan, and C. J. Howarth, 2002a: Quantitative trait loci associated with traits determining grain and stover yield in pearl millet under terminal drought- stress conditions. Theor. Appl. Genet. 104, 67-83.

Yadav, R. S., C. T. Hash, A. Sharma, F. R. Bidinger, K. M. Devos, J. R. Witcombe, and C. J. Howarth, 2002b: Marker assisted selection strategies to accumulate desirable QTLs in pearl millet. Plant, Animal \& Microbe Genomes Conference X, San Diego, California, USA, January, 12-16, 2002. Available at: http://www.intl-pag.org/pag/10/ abstracts/PAGX_W226.html (accessed 06.26.2007).

\section{Supplementary Material}

The following material is available online at http://www.blackwellsynergy.com

Table S1: Pedigree of pearl millet inbred lines used in the present study. Table S2: Annealing temperatures, linkage group and repeat motifs of 34 SSR markers used.

This material is available as part of the online article from http:// www.blackwell-synergy.com 